\title{
5 Slavery and the Law in Eighteenth-Century Germany
}

Among the many definitions of slavery, the legal definition is neither the only one nor even the one most commonly encountered in current research. As stated by Orlando Patterson in his classic Slavery and Social Death, legally defined systems of slavery represent exceptions in global history, and the legal situation is insufficient to describe the social, cultural, and mental dimensions of the state of enslavement adequately and without contradictions. ${ }^{1}$ Instead, Patterson cites violent domination, natal alienation, and dishonor as the three defining elements of slavery that differentiate it clearly from other forms of unfreedom. ${ }^{2}$ Michael Zeuske, on the other hand, uses the term "capitalization of bodies" to emphasize the aspect of economic exploitation even without legally existing slavery. ${ }^{3}$ According to Zeuske, focusing on the legally established institution obstructs the view onto the many concealed and smaller-scale forms of abduction and exploitation as well as onto the mutability and thus the continuity of enslavement practices from prehistory to the present. Other researchers highlight the transformation and overlapping of the status of enslavement with other forms of unfreedom and dependence such as war captivity, bondage, or servantship - but also aspects such as young age, female gender, extraneous religion, or dark skin color. They stress that only interdependent consideration of all these factors enables a thorough evaluation of the historical situation. ${ }^{4}$

All of these approaches highlight important facets. Against the background of the state of research on the Old Empire, however, which is characterized by noticeable restraint in employing the term "slavery" in connection with early modern Germany,

1 Orlando Patterson, Slavery and Social Death: A Comparative Study (Cambridge, MA: Harvard University Press, 1982), especially 21-22. According to Patterson, slaves were regularly legally called to account and punished for offenses even though they were assumed to have no legal capacity (ibid.).

2 Patterson, Slavery and Social Death, 10.

3 Michael Zeuske, Handbuch Geschichte der Sklaverei: Eine Globalgeschichte von den Anfängen bis zur Gegenwart (Berlin: De Gruyter, 2013), especially 1-26.

4 Cf. the contribution by Josef Köstlbauer in this volume as well as Stefan Hanß and Juliane Schiel, "Semantiken, Praktiken und transkulturelle Perspektiven," in Mediterranean Slavery Revisited 500-1800, ed. Stefan Hanß and Juliane Schiel (Zurich: Chronos, 2014), 25-43, here 29, 31-32, 36.

Notes: This project is funded by the European Research Council (ERC) within the framework of the EU research and innovation program "Horizon 2020" (ERC Consolidator Grant Agreement No. 641110: "The Holy Roman Empire of the German Nation and Its Slaves," 2015-2022). Nevertheless, this contribution exclusively expresses the author's opinion, and the ERC is not responsible for its contents or use.

Translation: Stephan Stockinger

Ә Open Access. (C) 2021 Rebekka von Mallinckrodt, published by De Gruyter. (c) BY-NC-ND This work is licensed under the Creative Commons Attribution-NonCommercial-NoDerivatives 4.0 International License.

https://doi.org/10.1515/9783110748833-006 
the legal dimension of enslavement obtains a new meaning and function: It represents the most tangible evidence of the existence of slavery practices if its theoretical validity can be documented alongside its practical application. That is precisely what this contribution intends to do.

To be sure, the economic involvement of German agents in the slave trade has been the object of research for some time now, ${ }^{5}$ and ample proof of Germans acting as plantation owners, slave overseers, and slave traders outside of Europe has been found. ${ }^{6}$ But researchers still continue to postulate a German exceptionalism in regard to the abduction of men and women of African and Asian descent to the Holy Roman Empire. According to Monika Firla or Andreas Becker, for instance, the slave status was nullified in the Empire either because German traders - in contrast to their European colleagues - merely "redeemed"7 slaves or because slaves were baptized as a matter of principle and thus placed on equal footing with domestics. ${ }^{8}$ Others like Peter Martin speak of a legal "no man's land between free and unfree

5 Cf. the contributions by Klaus Weber and Jutta Wimmler in this volume; see also Sarah Lentz, "OOh, Wonderful Sugar Beet! You Are the Death of the Bloody Sugar Cane.' The German Debate on the Morality of the Consumption of Sugar Produced by Slave Labour Around 1800," in Moralizing Commerce in a Globalizing World, ed. Felix Brahm and Eve Rosenhaft (Oxford: Oxford University Press, forthcoming); Anka Steffen and Klaus Weber, "Spinning and Weaving for the Slave Trade: Proto-Industry in Eighteenth-Century Silesia," in Slavery Hinterland: Transatlantic Slavery and Continental Europe, 1680-1850, ed. Felix Brahm and Eve Rosenhaft (Woodbridge: Boydell \& Brewer, 2016), 87-107; Klaus Weber, "Mitteleuropa und der transatlantische Sklavenhandel: Eine lange Geschichte," Werkstatt Geschichte 66/67 (2015): 7-30; Klaus Weber, "Deutschland, der atlantische Sklavenhandel und die Plantagenwirtschaft der Neuen Welt," Journal of Modern European History 7 (2009): 37-67; Michael Zeuske and Jörg Ludwig, "Amerikanische Kolonialwaren in Preußen und Sachsen: Prolegomena," Jahrbuch für Geschichte von Staat, Wirtschaft und Gesellschaft Lateinamerikas 32 (1995): 257-302; Peter Kriedte, "Vom Großhändler zum Detaillisten: Der Handel mit Kolonialwaren im 17. und 18. Jahrhundert," Jahrbuch für Wirtschaftsgeschichte 1 (1994): 11-36.

6 Cf. e.g. Mark Häberlein, “'Mohren', ständische Gesellschaft und atlantische Welt,” in Atlantic Understandings: Essays on European and American History in Honor of Hermann Wellenreuther, ed. Claudia Schnurmann and Hartmut Lehmann (Hamburg: Lit, 2006), 77-102; Sarah Lentz, “'[S]o kann ich jetzt als ein Augenzeuge auftreten.' Deutsche Profiteure des atlantischen Sklavereisystems und der deutschsprachige Sklavereidiskurs der Spätaufklärung," in Das Meer: Maritime Welten in der Frühen Neuzeit, ed. Peter Burschel and Sünne Juterczenka (Cologne: Böhlau, forthcoming); Carl Haarnack, "Duitsers in Suriname," Buku: Bibliotheca Surinamica, accessed June 26, 2020, https:// bukubooks.wordpress.com/duitsers.

7 Monika Firla, "AfrikanerInnen und ihre Nachkommen im deutschsprachigen Raum," in AfrikanerInnen in Deutschland und schwarze Deutsche: Geschichte und Gegenwart, ed. Marianne Bechhaus-Gerst and Reinhard Klein-Arendt (Münster: Lit, 2004), 9-24, here 15.

8 Andreas Becker, "Preußens schwarze Untertanen: Afrikanerinnen und Afrikaner zwischen Kleve und Königsberg vom 17. Jahrhundert bis ins frühe 19. Jahrhundert," Forschungen zur Brandenburgischen und Preußischen Geschichte 22 (2012): 1-32, here 15-16, 28. 
persons"9 or point explicitly to research gaps, as is the case in the recent contribution by Anne Kuhlmann-Smirnov. ${ }^{10}$

As current research has shown that despite possessing only few and short-lived colonies, the Old Empire resembled its European neighbors in many regards, ${ }^{11}$ it seems apposite to critically scrutinize this dimension of direct involvement in slavery in the German lands as well. Slavery was by no means an automatism that affected all individuals hailing from Africa or Asia in early modern Germany. Like in other European countries, we encounter a comparatively wide spectrum of legal, social, and economic dependency relations - as well as possibilities for action - for persons of African and Asian descent: Annika Bärwald, who emphasizes agency and the conscious choice of a cosmopolitan way of life in her chapter in this volume, documents one end of this spectrum, while my own contribution with its focus on the most radical form of unfreedom is dedicated to the other end of the range of possible - and existing - scenarios.

For this purpose, I have chosen Ludwig Julius Friedrich Höpfner (1743-1797), one of the best-known and most influential legal scholars in the second half of the eighteenth century who discussed the topic of slavery in his commentaries on Roman law as well as in his introduction to natural law. Both legal systems were used as subsidiary sources of law in the early modern Empire in areas where positive German law did not offer explicit regulations - as was the case with slavery. This was by no means unusual in comparison to other Western European countries like Great Britain, France, or the Netherlands, which likewise passed legislation on the legal status of enslaved persons on the European continent respectively on the British Isles only relatively late. It was apparently only during the course of the eighteenth century that the need for explicit legal provisions arose, conditioned by increasing mobility between the "motherland" and the colonies and with a view to the stability of the latter. Until this time, the trafficking in enslaved individuals from the colonies occurred in a legal grey area in most European countries. ${ }^{12}$

Since Höpfner as well as other contemporary legal experts gave precedence to positive (German and Roman) law and even to reason of state over natural law in the

9 Peter Martin, Schwarze Teufel, edle Mohren: Afrikaner in Geschichte und Bewußtsein der Deutschen (Hamburg: Hamburger Edition, 2001), 129: "Niemandsland zwischen Freien und Unfreien."

10 Anne Kuhlmann-Smirnov, Schwarze Europäer im Alten Reich: Handel, Migration, Hof (Göttingen: V \& R Unipress, 2013), 68-70.

11 For an overview, cf. the commented bibliography by Annika Bärwald, Josef Köstlbauer, and Rebekka v. Mallinckrodt, "People of African Descent in Early Modern Europe," Oxford Bibliographies Online: Atlantic History, ed. Trevor Burnard, last modified January 15, 2020, https://doi.org/10.1093/ obo/9780199730414-0326. See also the "Introduction" to this volume.

12 On this, cf. Rebekka v. Mallinckrodt, "Verhandelte (Un-)Freiheit: Sklaverei, Leibeigenschaft und innereuropäischer Wissenstransfer am Ausgang des 18. Jahrhunderts,” Geschichte \& Gesellschaft 43, no. 3 (2017): 347-380, here 352-356. 
case of conflict, ${ }^{13}$ I will focus on Höpfner's reception of Roman law in the following. ${ }^{14}$ The German jurist stood in a long tradition of implementing and modernizing Roman law extending back to the sixteenth century. The exponents of the socalled usus modernus pandectarum sought to adapt Roman legal principles to contemporary circumstances, thus striving for a modern application of Roman law. This legal school dominated German jurisprudence in teaching and judicature until the late eighteenth century. ${ }^{15}$ Alternative legal sources on slavery like the application of colonial law in Europe were likewise taken into consideration by Höpfner's juristic colleagues, however, as I will demonstrate in the second part of this contribution. It investigates the Yonga case, a trial in which the status of a person abducted to Germany was explicitly tried and decided - thereby documenting whether and how the legal principles discussed in the first section were also applied in practice.

\section{"Negro and Turkish Slaves" in the Old Empire from the Perspective of the Jurist Ludwig Julius Friedrich Höpfner (1743-1797)}

Ludwig Julius Friedrich Höpfner was born in 1743 as the son of a law professor from Giessen, who started preparing him for an academic career early on together with Ludwig's likewise highly educated mother. Höpfner junior began his studies at the University of Giessen as early as 1756. After several years as educator to the family of jurist and State Minister von Kanngießer in Kassel, Höpfner taught law at the

13 Michael Plohmann, Ludwig Julius Friedrich Höpfner (1743-1797): Naturrecht und positives Privatrecht am Ende des 18. Jahrhunderts (Berlin: Duncker \& Humblot, 1992), passim, especially 21, 79-81, 251, 253; Jan Schröder, “'Naturrecht bricht positives Recht' in der Rechtstheorie des 18. Jahrhunderts?” in Staat, Kirche, Wissenschaft in einer pluralistischen Gesellschaft: Festschrift zum 65. Geburtstag von Paul Mikat, ed. Dieter Schwab et al. (Berlin: Duncker \& Humblot, 1989), 419-433; Ines Pielemeier and Jan Schröder, "Naturrecht als Lehrfach an den deutschen Universitäten des 18. und 19. Jahrhunderts," in Naturrecht Spätaufklärung - Revolution, ed. Otto Dann and Diethelm Klippel (Hamburg: Meiner, 1995), 255-269, here 266, 268; Christoph Ulmschneider, Eigentum und Naturrecht im Deutschland des beginnenden 19. Jahrhunderts (Berlin: Duncker \& Humblot, 2003), 133; Thomas Cornelius Kischkel, "Das Naturrecht in der Rechtspraxis: Dargestellt am Beispiel der Spruchtätigkeit der Gießener Juristenfakultät," Zeitschrift für Neuere Rechtsgeschichte 22 (2000): 124-147, here 141; Diethelm Klippel, "Politische und juristische Funktionen des Naturrechts in Deutschland im 18. und 19. Jahrhundert. Zur Einführung," Zeitschrift für Neuere Rechtsgeschichte 22 (2000): 3-10, here 8.

14 On Höpfner's stance in terms of natural law, cf. Rebekka von Mallinckrodt, "Sklaverei und Recht im Alten Reich,” In Das Meer: Maritime Welten in der Frühen Neuzeit, ed. Peter Burschel and Sünne Juterczenka (Cologne: Böhlau, forthcoming).

15 Martin Heger, “Recht im 'Alten Reich': Der Usus modernus," Zeitschrift für das Juristische Studium 1 (2010): 29-39. 
Kassel Carolinum from 1767. In 1771, he was appointed to the University of Giessen by the state sovereign as a regular professor of law, where he obtained his doctorate in the same year. The order of these events was unusual even for the time and may explain Höpfner's subsequent stabilitas loci. He declined calls to the universities in Jena and Göttingen in 1776, 1777, and $1782,{ }^{16}$ instead becoming increasingly involved in the Hessian state administration. After becoming a member of the State Council of Hesse-Darmstadt in 1778, he was transferred to the Oberappellationsgericht (High Appeals Court) in Darmstadt in 1781 and promoted to Privy Tribunal Council (Geheimer Tribunalrat) a year later. ${ }^{17}$ The majority of his works were thus published at a time when he was no longer exclusively engaged in teaching and research but instead tasked with more practical duties like those of a judge or the preparation of a collection of the Hesse-Darmstadt state ordinances and the draft of a Hessian Landrecht or land law (both of which remained uncompleted owing to Höpfner's death in 1797).

This practical orientation did nothing to detract from his scientific reputation or the dissemination of his writings, however. His two main works Naturrecht des einzelnen Menschen[,] der Gesellschaften und der Völker (Natural Law of the Individual Human, of Societies, and of Peoples, 1780) and Theoretisch-practischer Commentar über die Heineccischen Institutionen (Theoretical-Practical Commentary on the Heineccian Institutions, 1783) were published in multiple editions and became standard reading for legal education during Höpfner's lifetime. This appears unusual from a present-day perspective in the case of the Commentar, since its title indicated that it represented its author's views on the interpretation of the Roman institutions by Johann Gottlieb Heineccius (1681-1741) and was thus a second-order commentary. In fact, Höpfner had originally published Heineccius' treatise, the most widely used textbook on the Roman institutions at the time, as editor before having a revised edition printed as his own commentary. Since he adopted certain aspects, he kept a reference to the original author in the title. ${ }^{18}$ A significant difference to Heineccius' approach, however, was that Höpfner dedicated more space to contemporary

16 Plohmann, Höpfner, 22 and 24.

17 This and the following: Christoph Weidlich, Biographische Nachrichten von den jetztlebenden Rechts-Gelehrten in Teutschland, vol. 1 (Halle: Hemmerde, 1781), 310-312; Friedrich Wilhelm Strieder, Grundlage zu einer Hessischen Gelehrten- und Schriftsteller-Geschichte, vol. 6 (Cassel: Cramer, 1786), 54-59.

18 Ludwig Julius Friedrich Höpfner, Theoretisch-practischer Commentar über die Heineccischen Institutionen, $1^{\text {st }}$ ed. (Frankfurt: Varrentrapp \& Wenner, 1783), Vorrede [no pagination]. Among other aspects, Höpfner adopted the so-called "axiomatic method" that had made Heineccius famous; it derived concrete rules from definitions and general tenets, linking them to the corresponding passages in Roman law. This enabled law students to understand - and more importantly to remember - the material more easily. Cf. Patricia Wardemann, Johann Gottlieb Heineccius (1681-1741): Leben und Werk (Frankfurt: Peter Lang, 2007), 23-32. 
interpretation and thus to practical application - which in turn makes him particularly significant for the purpose of our present study.

Michael Plohmann stated about Höpfner in his 1992 doctoral thesis: "[ . . . ] that Höpfner definitely wrote the most important book of his time on civil law with the Commentar and the most influential textbook on natural law with the Naturrecht. Proponents and detractors of the works alike see Höpfner as the representative of German legal studies during the late eighteenth century."19 Even in the nineteenth century, when the "historical school of law" superseded the usus modernus pandectarum and began to critically distance itself from this current, ${ }^{20}$ Friedrich Carl von Savigny retrospectively wrote about Höpfner: "His most important work, the Institution Commentary (1783), stood [ . . . ] in the highest repute, and not without reason. Indeed, our juristic literature cannot boast many works in the German language that are as deserving as this one of being mentioned as truly readable books due to their good, clear presentation."21

Höpfner published six editions of the Theoretisch-practischer Commentar between 1783 and 1798. He also had an indirect impact through various plagiarisms of his works. ${ }^{22}$ After his death, Adolph Dietrich Weber (1753-1817) put a seventh and eighth edition to print in 1803 and 1804, which were republished in 1818 and 1833 respectively - but by that time, the book's influence had waned.

19 Plohmann, Höpfner, 34: “[ . . . ] daß Höpfner mit dem Kommentar in jedem Fall das wichtigste Zivilrechtsbuch und mit dem Naturrecht das einflußreichste Naturrechtslehrbuch seiner Zeit geschrieben hat. Anhänger und Gegner der Werke sehen in Höpfner den Repräsentanten der deutschen Rechtswissenschaft am Ausgang des 18. Jahrhunderts." Cf. also ibid., 27: "Unerreicht war die Bedeutung des Kommentars für die gemeinrechtliche Wissenschaft und Praxis in Deutschland am Ende des 18. Jahrhunderts bis weit in das 19. Jahrhundert hinein. Es handelte sich um ein Standardwerk, das in keiner juristischen Bibliothek fehlte. Höpfners großer wissenschaftlicher Gegenspieler, der Göttinger Rechtsprofessor Gustav Hugo, spricht [ . . . ] 1827 gar davon, daß erst zu dieser Zeit möglicherweise von einer langsamen Verdrängung des Höpfnerschen Kommentars gesprochen werden könne." "“The importance of the Commentar for the science and practice of common law in Germany at the end of the eighteenth century until well into the nineteenth century was unmatched. It was a standard work that was absent from no legal library. Höpfner's great academic opponent, the Göttingen professor of law Gustav Hugo, stated [ . . . ] in 1827 that only at this time could one perhaps speak of a slow displacement of Höpfner's Commentar.")

20 Plohmann, Höpfner, 30-33.

21 Friedrich Carl v. Savigny, "Der zehente Mai 1788: Beytrag zur Geschichte der Rechtswissenschaft," Zeitschrift für geschichtliche Rechtswissenschaft 9 (1838): 421-432, here 427: "Sein wichtigstes Werk, der Institutionencommentar (1783), stand [ . . . ] im höchsten Ansehen, und nicht ohne Grund. In der Tat hat unsere juristische Literatur nicht viele Werke in deutscher Sprache aufzuweisen, die so wie dieses durch gute, klare Darstellung als wirklich lesbare Bücher genannt zu werden verdienen." See also Alfred Söllner, "Ludwig Julius Friedrich Höpfner - ein Mitglied der Gießener Juristenfakultät im 18. Jahrhundert," in Festschrift für Walter Mallmann, ed. Otto Triffterer and Friedrich von Zezschwitz (Baden-Baden: Nomos, 1978), 281-292, here 291.

22 Johann G. Meusel, Lexikon der vom Jahr 1750 bis 1800 verstorbenen teutschen Schriftsteller, vol. 8 (Leipzig: Fleischer, 1806), 12-15, here 14. Cf. also Plohmann, Höpfner, 26-27. 
Höpfner was not considered an innovator or shaker but rather a particularly reliable, comprehensible, and practice-oriented compiler of the positions regarded as the contemporary state of the art. ${ }^{23}$ The fact that his Commentar originated directly from his teaching and was continually improved through its use and application likely contributed to its accessibility. ${ }^{24} \mathrm{He}$ was also an extremely popular and successful university lecturer, and thus influenced the legal discipline not only through his publications but also by way of direct interaction. ${ }^{25}$

The following pages make use of all the editions of the Theoretisch-practischer Commentar overseen by Höpfner himself, with the aim of documenting his views at specific points in time as well as determining possible changes of opinion. Already in the very first edition in 1783 , he wrote:

\section{$\S .70$ On present-day slavery.}

We have today 1) true slaves in the sense of Roman law, 2) serfs; 3) free servants and maids. True slaves are the Negro slaves and the captured Turks. For as the Turks turn our prisoners of war into slaves, so we proceed in the same way with theirs. The Turkish slaves are not likely encountered in Germany at this time since we have not conducted any wars with the Turks for so long. Negro slaves, however, are sometimes brought to us from Holland and other empires. Both kinds of slaves are to be adjudged according to Roman law, for Roman law is accepted in its entirety. The King of Prussia has confirmed these clauses in one of his own resolutions by recognizing that a Moor purchased in Copenhagen and brought to the Prussian lands cannot demand freedom simply because he is now living in Prussia. ${ }^{26}$

23 Plohmann, Höpfner, 72, 250. Hence Johannes Deissler's characterization of Höpfner as "juristischer Antiquar" ("juristic antiquarian") is unfounded: idem, Antike Sklaverei und deutsche Aufklärung im Spiegel von Johann Friedrich Reitemeiers "Geschichte und Zustand der Sklaverey und Leibeigenschaft in Griechenland” 1789 (Stuttgart: Steiner, 2000), 96.

24 Cf. Friedrich Schlichtegroll, Nekrolog auf das Jahr [ . . . ], vol. 8,2 (Gotha: Perthes, 1797, published 1802), 319-332, here 327-328: "Dies treffliche Buch hat bey seiner großen Klarheit, und bey der Verbindung des Praktischen mit dem Theoretischen, sehr viel Gutes gewirkt; sechs starke Auflagen zeugen davon, wie allgemein es gebraucht wurde; bey jeder wurde es verbessert, wozu dem Verf. eben die erwähnten Vorlesungen, bey welchen er es jedesmal von neuem durchging, beförderlich waren." ("This splendid book has produced much good with its great clarity, and with its connection of the practical with the theoretical; six strong editions prove how universally it was used; with each it was improved, for which the mentioned lectures, during which he went through it anew each time, served the author well.”). Cf. also Plohmann, Höpfner, 25; Söllner, "Höpfner,” 290. 25 Söllner, "Höpfner," 284-289.

26 Höpfner, Commentar, $1^{\text {st }}$ ed. 1783, 67: "§. 70 Von der heutigen Sklaverey: Wir haben heutzutage 1) wahre Sklaven im Sinne des römischen Rechts, 2) Leibeigene; 3) freye Knechte und Mägde. Wahre Sklaven sind die Negersklaven und die gefangene Türken. Denn da die Türken unsere Kriegsgefangene zu Sklaven machen, so verfahren wir mit den ihrigen auf gleiche Weise. Die Türkensklaven trift man jetzt in Teutschland wohl nicht an, da wir so lange keine Kriege mit den Türken geführt haben. Negersklaven aber werden zuweilen aus Holland und andern Reichen zu uns gebracht. Beyde Arten von Sklaven sind nach römischem Recht zu beurtheilen. Dann das römische Recht ist im ganzen angenommen. Der König in Preussen hat diese Sätze durch eine eigenhändige Resolution bestätiget, indem er erkannt hat, daß ein in Koppenhagen erkaufter und in die 
Taking into consideration the preceding Articles 61 to 69 regarding the rights of persons, Höpfner held "true slaves in the sense of Roman law" to mean that slaves were considered humans according to Roman natural law (for example, a contract was binding for them in the same way it was for other persons, and the incest prohibition applied to them $)^{27}$ but not persons in the sense of positive Roman law:

Whoever has no civic status is not a person but instead assigned to the class of things. Such are the slaves (servi) according to Roman law. They possess not a single civic status, no rights whatsoever in the Roman state; they are therefore not regarded as persons but as things, res. ${ }^{28}$

Slavery is thus defined as rightful dominion over a human being. ${ }^{29}$ One could be born into slavery as the child of a slave ("Whether this conforms to natural law is a question that does not belong here. Sufficient that the Roman laws decree it.”) or become enslaved through war captivity (which Höpfner disapproved of with reference to Montesquieu and Rousseau) or as punishment for deception of a purchaser who believed to be buying a slave. Slavery could also be imposed as a penalty for other crimes as well as for ingratitude towards the redeemer. On the other hand, voluntarily selling oneself into slavery was not possible. Several articles later, Höpfner explains what slavery meant in early modern contemporary practice:

\section{§. 97. Present-day usage.}

The provisions of Roman law still apply to the true slaves today. (§. 70.) For example, whoever owns a captured Turk or Negro slave has the right to sell him and make everything the slave acquires his own. He does not have the power over life and death, however, only the right to castigate moderately. Roman law is not applicable to serfs, which are adjudged according to German laws and customs. ${ }^{30}$

Preußische Lande eingebrachter Mohr, blos aus dem Grunde, weil er im preußischen lebe, nicht auf die Freyheit provociren könne." On the mentioned case, cf. Mallinckrodt, "Verhandelte (Un-)Freiheit," 347-348, 362-370. It was the so-called "Rechtsgeschichte eines erkauften Mohren” (Beyträge $z u$ der juristischen Litteratur in den preußischen Staaten 6. Sammlung, 4. Abschnitt (1780): 296-319), which did not end with a court verdict but instead with the rejection of an African slave's petition aiming to prevent his sale to a new owner.

27 Höpfner, Commentar, $1^{\text {st }}$ ed. 1783, 64. On natural law conceptions in Roman law, cf. Jakob F. Stagl, "Die Personwerdung des Menschen: Anfänge im Römischen Recht," in Personen: Zum Miteinander einmaliger Freiheitswesen, ed. Hans Thomas and Johannes Hattler (Berlin: De Gruyter, 2012), 89-109.

28 Höpfner, Commentar, $1^{\text {st }}$ ed. 1783, 62: "Wer keinen bürgerlichen Zustand hat, ist keine Person, sondern wird in die Classe der Sachen gerechnet. Dergleichen sind nach römischem Rechte die Sklaven (servi). Sie haben keinen einzigen bürgerlichen Zustand, gar keine Rechte im römischen Staat; daher werden sie auch nicht als Personen, sondern als Sachen, res angesehen.” Cf. also ibid., 64.

29 This and the following Höpfner, Commentar, $1^{\text {st }}$ ed. 1783, 63-66: "Ob dieß dem Naturrecht gemäs sey, ist eine Frage, die nicht hierher gehört. Genug, daß es die römische Gesetze verordnen.” 30 Höpfner, Commentar, $1^{\text {st }}$ ed. 1783, 81: "§. 97. Heutiger Gebrauch: Die Verordnungen des römischen Rechts haben noch heutzutag bey den wahren Sklaven statt. (§. 70.) Wer z[um] E[xempel] einen gefangenen Türken oder Negersklaven besitzt, der hat das Recht ihn zu veräussern, und alles 
This rejection of the application of Roman law to indigenous serfs, ${ }^{31}$ a view commonly advanced in contemporary sources, presumably contributed to the belief persisting until today that there were no slaves in the Old Empire. In fact, however, Höpfner applied the legal status of slavery to foreigners - the abovementioned "captured Turks or Negro slaves" - and thus to persons differing in terms of their skin color and/or religion from the natives on whom he apparently did not wish to impose such an utter lack of rights.

In Roman law, as well as in its modern interpretation, the consequences of the status of enslavement did not end with manumission. In contrast to serfs, the owner of a "true slave" maintained a right of patronage over the enslaved even after the latter had been freed:

$\S .83$. On the present-day usage of this matter.

[ . . . ] Whoever wishes to manumit a serf gives him a document known as a letter of release, and such serf is then as free as any other person; the right of patronage ceases to exist for him. I have my doubts whether this can also be claimed if someone manumits a Negro slave; and I believe that Roman law must be applied in this case; meaning that the manumitter is indeed entitled to the rights of patronage over the manumitted. ${ }^{32}$

In the historical part of his explanation, Höpfner declared with reference to freed slaves that "a libertus had his patron to thank for much." 33 The patron was therefore

sich zuzueignen, was der Sklav erwirbt. Das Recht über Leben und Tod aber hat er nicht, sondern nur das Recht mässig zu züchtigen. Auf Leibeigene läßt sich das römische Recht nicht anwenden, diese werden nach deutschen Landesgesetzen und Gewohnheiten beurtheilt.”

31 For the second half of the eighteenth century, cf. e.g. Johann Gottfried Schaumburg, Einleitung zum Sächsischen Rechte, $2^{\text {nd }}$ ed., vol. 1 (Dresden: Gerlach, 1768), 90; Justus Friedrich Runde, Grundsätze des allgemeinen deutschen Privatrechts (Göttingen: Johann Christian Dieterich, 1791), 339, § 483, 389, § 536. Runde also differentiated serfdom from slavery "des heutigen Völkerrechts" ("as per contemporary international law") respectively "der in beyden Indien üblichen Sclaverey” ("the slavery customary in both Indias"), ibid. For a greater temporal scope, cf. also Winfried Schulze, "Die Entwicklung eines 'teutschen Bauernrechts' in der Frühen Neuzeit," Zeitschrift für Neuere Rechtsgeschichte 12 (1990): 127-163, especially 162; Peter Blickle, Von der Leibeigenschaft zu den Menschenrechten: Eine Geschichte der Freiheit in Deutschland (Munich: C. H. Beck, 2006), 133-134, 265, 272, 276-277; Marion Wiese, Leibeigene Bauern und Römisches Recht im 17. Jahrhundert: Ein Gutachten des David Mevius (Berlin: Duncker \& Humblot, 2006); Luca Scholz, "Leibeigenschaft rechtfertigen: Kontroversen um Ursprung und Legitimität der Leibeigenschaft im Wildfangstreit," Zeitschrift für Historische Forschung 45, no. 1 (2018): 41-81, here 57-58.

32 Höpfner, Commentar, $1^{\text {st }}$ ed. 1783, 73: “§. 83. Vom heutigen Gebrauche dieser Materie: [ . . . ] Wer einen Leibeigenen frey lassen will, giebt ihm ein Document, das ein Laßbrief heist, und ein solcher Leibeigener ist nun so frey, als ein anderer Mensch; das Patronatsrecht fällt bey ihm weg. Ob aber dies auch behauptet werden kann, wann jemand einen Negersklaven frey läßt, daran zweifle ich; und glaube, daß in diesem Fall das römische Recht angewandt werden müsse; folglich dem Freylasser die Patronatsrechte über den Freygelassenen allerdings zustehen.”

33 Höpfner, Commentar, $1^{\text {st }}$ ed. 1783, 73, § 81: "Ein libertus hatte seinem Patron viel zu danken.” 
viewed as the closest relative, as the father of the manumitted, and the freed slave consequently adopted the patron's name $(\S 81)$. The manumitted also owed the patron obeisance, and failure to render it could result in reversion to the enslaved status. He was furthermore obliged to perform honorary services like escorting at public appearances or manual labor, though only if it had been promised (which was very likely if an enslaved individual hoped that giving such promise would secure his freedom). Finally, the patron inherited between one-third and the entirety of the property of the manumitted if the latter died without children (§ 82). Since Höpfner neither modified nor reinterpreted the rights of patronage in a modern sense, he appears to have considered them still applicable to "true slaves in the sense of Roman law" in the eighteenth century. In order to exclusively document undoubtedly contemporary positions, however, I will limit myself in the following to those passages in which Höpfner explicitly discusses "present-day usage" - that is, the Articles 70, 83, and 97 cited above.

The second and third editions published in 1787 respectively 1790 include the passages cited above in identical wording. As orthographic changes and the addition of a literature reference prove, however, they were not simply reprinted without modification but in fact reviewed and updated; they can therefore be assumed to reflect the state of the legal discourse at the time of their printing. The same applies to the fourth edition produced in $1793 .{ }^{34}$ In the fifth edition of 1795 , Höpfner replaced the Prussian case study in Article 70 with a general and more vehemently phrased statement: "and I am not of the opinion that slavery is completely abolished here, so that a slave who comes to Germany immediately becomes free."35 Höpfner presumably used this phrasing to distance himself from the abrogation of slavery in the "neues Preußisches Gesetzbuch," the general land law for the Prussian states passed in 1794 and mentioned in the associated footnote. While it did not apply to Hesse, where Höpfner worked, this abolition offered an alternative legal model. At the same time, however, it stipulated that freed slaves had to serve their former owner without remuneration until the latter had recouped their purchase costs. ${ }^{36}$ They could also be "allocated to a manor as subjects," meaning that they were bound

34 Höpfner merely deleted the sentence "Die Türkensklaven trifft man jetzt in Deutschland wohl nicht an, da wir so lange keine Kriege mit den Türken geführt haben" ("The Turkish slaves are not likely encountered in Germany at this time since we have not conducted any wars with the Turks for so long”) and replaced "der König in Preußen" ("the King of Prussia”) with "König Friedrich II." (King Frederick II) in order to prevent confusion with the Frederick's successor Frederick William II. 35 Höpfner, Commentar, $5^{\text {th }}$ ed., 1795, 90, § 70: "und ich bin nicht der Meynung, daß die Sklaverey bey uns ganz abgeschafft sey, folglich ein Sklave, der nach Deutschland kommt, sogleich frey werde.”

36 Allgemeines Landrecht für die Preußischen Staaten von 1794, ed. Hans Hattenhauer and Günther Bernert, $2^{\text {nd }}$ ed. (Neuwied: Luchterhand, 1994), 431, Theil II, Titel V, § 202. See also ibid., 431-432, § 203-205. 
to the manor and obligated to provide labor. ${ }^{37}$ Hence manumission did not necessarily result in freedom in the Prussian lands either, since the status of enslavement could be converted into a different form of unfreedom, namely serfdom.

In 1795, Höpfner also added a sentence on the manumission of slaves to Article 83, an indication of the practical need to address this question: "A slave is manumitted by way of an oral or written declaration without any ceremony." 38 This relatively informal arrangement in comparison to the letter of release received by serfs may explain why hardly any manumission documents are preserved today. It is also understandable when one considers that in contrast to serfs, enslaved persons were to remain subject to powers of patronage for the rest of their lives - in other words, their manumission did not necessarily entail a change in their concrete conditions of living. Finally, in the last edition overseen by Höpfner himself in 1798, he confirmed and emphasized his position: "and I am not of the opinion that a slave who comes to Germany immediately becomes free, since neither does an explicit German law prescribe this nor can a general custom of this type be proven." [italics added RvM] ${ }^{39}$ A widely used and highly praised legal textbook on Roman law thus not only contained repeated confirmation of slave status in the Old Empire but also increasingly emphasized property rights over enslaved persons.

By contrast, Gustav Hugo (1764-1844), professor of law in Göttingen and Höpfner's "great academic adversary," 40 challenged the notion that Roman law was applicable to slaves in Germany. In an article in the Civilistisches Magazin, Hugo responded to a reviewer's critique of his Institutionen des heutigen Römischen Rechts (Institutions of Present-Day Roman Law) complaining that the book made no mention of slaves in the Holy Roman Empire: The problem, Hugo replied, was quantitatively negligible. ${ }^{41}$ This comes as a surprise when one considers that Hugo lived in Göttingen, roughly 40 kilometers from Kassel, where more than 100 free, unfree, and manumitted African-American men, women, and children lived in the 1780s, having arrived in the Old Empire with the Hessian troops after the American Revolutionary War. ${ }^{42}$ Hugo made only passing reference

37 Allgemeines Landrecht, 432, § 207: “einem Landgute als Unterthanen zuschlagen.” On further provisions regarding released slaves, cf. Mallinckrodt, "Verhandelte (Un-)Freiheit," 370-371; Rosenhaft v. Mallinckrodt, “There Are No Slaves in Prussia?” in Slavery Hinterland, ed. Brahm and Rosenhaft, 109-131, here 129-130.

38 Höpfner, Commentar, $5^{\text {th }}$ ed. 1795, 96, § 83: "Einen Sklaven manumittiret man durch eine mündliche oder schriftliche Erklärung ohne Feyerlichkeiten.”

39 Höpfner, Commentar, $6^{\text {th }}$ ed., 1798, 98, § 70: "und ich bin nicht der Meynung, daß ein Sklave, der nach Deutschland kommt, sogleich frey werde, da weder ein ausdrückliches deutsches Gesetz dieses vorschreibt, noch eine allgemeine Gewohnheit dieser Art erwiesen werden kann." My emphasis marks the subordinate clause added by Höpfner in 1798.

40 Plohmann, Höpfner, 27: “großer wissenschaftlicher Gegenspieler.”

41 Gustav Hugo, Civilistisches Magazin, vol. 1 (Berlin: Mylius, 1791), 356-357.

42 Maria I. Diedrich, "From American Slaves to Hessian Subjects: Silenced Black Narratives of the American Revolution," in Germany and the Black Diaspora: Points of Contact 1250-1914, ed. Mischa Honeck, Martin Klimke, and Anne Kuhlmann (New York: Berghahn, 2013), 92-111, here 93. 
to "the reasoning of the majority that we still have slaves iure retorsionis," 43 which he rejected for Africans in contrast to Turks "if one does not, as was of course formerly done, consider them to be the same [as the latter], since they are also infidels." 44 Instead, he advocated the application of colonial law in such cases:

From the fact that we have slaves [sic], and that slaves occur in Roman law, it by no means follows that we must apply Roman law in this matter. [ . . . ] would one not rather also protect everyone here in his rights that he had acquired through the jurisprudence of the other state and wished to exercise? [ . . . ] Are you not willing to at least regard the right of the colonies as a tacit condition under which the slave came to his master? ${ }^{45}$

Despite his criticism of Höpfner, these statements by Hugo provide further evidence that slavery was not only a legal concept in the Old Empire but that it also existed in practice - and that, according to Hugo, the majority viewed slavery as justifiable according to the law of retaliation (iure retorsionis). The controversy between Hugo and Höpfner could be dismissed as legal finger exercises and intellectual shadow boxing were it not for the Yonga trial, which proves that such disputes had practical relevance for jurisdiction. This extraordinarily well-documented court case shows which arguments the opposing parties furnished for and against slave status in the Holy Roman Empire and which ones were decisive for the court's verdict.

\section{The Yonga Trial}

In 1790, the African servant Franz Wilhelm Yonga filed suit against his former master and owner, privy counsellor Franz Christian von Borries (1723-1795), at the High Princely Chancellery in Detmold as the highest court in the Principality of Lippe. ${ }^{46}$ The lawsuit was motivated by Borries' transfer of ownership of Yonga to Count (and from 1790, Prince) Leopold of Lippe in June 1789, which caused Yonga to fear for the pension provision he had hoped to receive from Borries in return for his unpaid

43 Hugo, Civilistisches Magazin, 356: "das Raisonnement der Majorität, wir hätten noch Sclaven iure retorsionis."

44 Hugo, Civilistisches Magazin, 357: "wenn man sie nicht, wie freylich ehemahls geschah, mit diesen ganz für einerley hält, weil sie doch auch Unglaubige seyen."

45 Hugo, Civilistisches Magazin, 358-360: "Daraus daß wir Sclaven haben [sic], und daß im Römischen Rechte Sclaven vorkommen, folgt noch gar nicht, daß wir also das Römische Recht hierin anwenden. [ . . . ] würde man nicht vielmehr auch bey uns jeden bey seinen Rechten schützen, die er nach der Jurisprudenz des andern Staats erlangt hätte und ausüben wollte? [ . . . ] Wollt Ihr das Recht der Colonien nicht wenigstens als eine stillschweigende Bedingung ansehen, unter welcher der Sclave an seinen Herrn kam?”

46 The trial records can be found in the extensive file L 83 A Nr. 12 J 247 at the Staatsarchiv Detmold. Further records pertaining to Yonga and his family were consulted supplementarily (Staatsarchiv Detmold, L 77 B Nr. 129; L 92 A Nr. 1190; L 92 P Nr. 120; L 98 Nr. 62; L 114 v. Borries Nr. 4). 
service. Yonga's legal status was therefore only indirectly a matter of interest in the suit. At its core, the trial was about whether Borries should have been paying Yonga during the previous twenty-two years or whether Yonga had no right to such reimbursement as a slave. In the course of the proceedings, gratuities that Borries claimed to have retained on behalf of Yonga and that the former servant now demanded back became a further topic of dispute.

Borries had purchased Yonga in 1765 as a 14-year-old boy from "ship captain Gorden, a very distinguished well-known slave trader in London." ${ }^{47}$ Borries had been stationed in the British capital as Prussian envoy since 1763 and eventually returned to the County of Lippe with Yonga after traveling to several other countries. ${ }^{48}$ Borries evidenced the fact that he still considered Yonga his personal property in 1789 - long after returning to the Empire - not only by furnishing the contract of purchase but also in the phrasing of the transfer agreement:

The Negro slave Yonga, purchased lawfully and legally as my possession and property according to the bill of sale, who since he was conveyed to baptism is called Franz Wilhelm: I present, transfer, and consign herewith, as he belongs to me as my property, to lifelong service to the Lord Hereditary Count Leopold, my most gracious Count and Lord, as a small token of my most humble devotion, without any further claim or reservation. ${ }^{49}$

It was precisely this status that Yonga disputed: For twenty-six years, he stated, he had served Borries faithfully, of which " 4 years as a so-called Moor slave and 22 years as a Christian in the function of barber, shaver, and table-setter - without receiving wages." ${ }^{50}$ Yonga himself apparently assumed that he had been manumitted with his baptism, even though he remained unpaid thereafter.

Although the available sources are written in the first person and with much pathos, it is impossible to distinguish between Yonga's voice and that of his attorney

47 Staatsarchiv Detmold, L 83 A Nr. 12 J 247, fol. 30r: "Schifs-Capitain Gorden ein[em] sehr angesehene $[\mathrm{m}]$ bekandte[m] Sclaven-Händler in London."

48 Acta Borussica: Denkmäler der Preußischen Staatsverwaltung im 18. Jahrhundert, ed. Preußische Akademie der Wissenschaften, vol. 13 (Berlin: Parey, 1932), 610-611. According to Borries, he and Yonga had "in [ . . . ] vieler Herren Lande in und außer deutschland und über 16 Jare in hiesiger Grafschaft befunden" ("been in the lands of many lords within and outside of Germany and in this County for more than 16 years") (Staatsarchiv Detmold, L 83 A Nr. 12 J 247, fol. 29v).

49 Staatsarchiv Detmold, L 98 Nr. 62 [unfoliated], transfer agreement as supplement to the purchase contract: "Den vermöge des vorstehenden kaufbriefes [ . . ] rechtlich und gesetzlich als mein Guth und Eigenthum erkauften Neger-Sklaven Yonga, welcher hiernechst da ihn zur Tauff beferdert Frantz Wilhelm genant: präsentire, übertrage und übergebe hiedurch, so wie er mir mit Eigenthum angehörig, zum lebenswierigen dienst des Herrn Erb-Grafen Leopold, meines gnädi[g]sten Grafen und Herren, als ein geringes Merkmahl meiner untertänigen devotion, ohne allen weitern Anspruch und Vorbehalt.”

50 Staatsarchiv Detmold, L 83 A Nr. 12 J 247, fol. 3v: “4 Jahre als ein sogenannter Mohren Sklav, und 22 Jahr als Christ in der Qualitaet als Friseur, Raseur und Tafel-deker, - ohne Lohn zu erhalten.” 
Antze, ${ }^{51}$ who had been assigned to him pursuant to poor laws. Legal knowledge and phrasing point to the lawyer as co-author and sometimes explicitly main author - as was the case with various documents on Borries' side. What is more, both parties employed different and sometimes contradictory lines of argumentation in the course of the trial, meaning they effectively did not follow a single, well-defined strategy but instead brought forth any and all arguments that might potentially yield success. They also challenged their respective opponent's argumentation wherever it appeared opportune, with Yonga eventually not only disputing that he had been Borries' slave after 1770 , the year of his baptism, ${ }^{52}$ but that he had ever been rightfully enslaved at all. Hence the arguments for and against Yonga's status of enslavement will be grouped around two central questions in the following, regardless of when they were furnished during the proceedings and whether they were verbalized by the plaintiff or defendant himself or their respective lawyers (if such distinction is possible at all):

a) Could Borries lawfully purchase Yonga as a slave in the first place, and

b) how should Yonga's legal status within the Holy Roman Empire be evaluated?

Borries remarked on several occasions that he had purchased Yonga in London "with all solemnities legally required there," 53 making reference to a so-called "slave law black law" ${ }^{54}$ respectively "the strict slave laws according to which I purchased [him] in loco contractus, and [which] the decision must be based upon." ${ }^{55}$ As no such slavery laws existed in Great Britain, Borries was apparently suggesting the purchase had taken place under the laws of the colony, in this case Antigua, that the ship captain regularly traveled to. ${ }^{56}$ While Antigua had no specific "black law" - a term that was presumably intended to allude to the "Code Noir" for the French colonies - it did have extensive legislation on slavery. Like Roman law, these colonial laws largely denied slaves the status of persons; they could be traded, bequeathed, and even mortgaged as property. Draconic punishments were in place to prevent escape and revolts, while laws for the protection of enslaved individuals played an entirely subordinate role. ${ }^{57}$

51 As the first name is missing, the attorney cannot be identified with certainty. Johannes Arndt mentions several jurists with the last name Antze: Johannes Arndt, Das Fürstentum Lippe im Zeitalter der Französischen Revolution 1770-1820 (Münster: Waxmann, 1992).

52 Wolfgang Bechtel researched Yonga's family history in a genealogical article: "Der 'Kammermohr’ Franz Wilhelm Yonga,” Lippische Mitteilungen aus Geschichte und Landeskunde 84 (2015): 11-35, here 14.

53 Staatsarchiv Detmold, L 83 A Nr. 12 J 247, fol. 8r: "mit allen daselbst Gesetz-erforderlichen Sollemnitäten”; a similar phrasing ibid., fol. 29v.

54 For example in the transfer agreement Staatsarchiv Detmold L 98 Nr. 62 [unfoliated].

55 Staatsarchiv Detmold, L 83 A Nr. 12 J 247, fol. 8v: "die strengen sklaven gesetze wonach ich [ihn] in loco contractus erkauft, und [die] der entscheidung zum grunde gelegt werden müssten."

56 Staatsarchiv Detmold, L 98 Nr. 62 [unfoliated].

57 The Laws of the Island of Antigua: Consisting of the Acts of the Leeward Islands, Commencing 8th November 1690, ending 21st April 1798; and the Acts of Antigua, Commencing 10th April 1668, 
Though he did not mention him by name, Borries' argumentation was thus similar to Gustav Hugo's in that he assumed the validity of colonial law to extend all the way to Europe.

Yonga's side objected that - even if the purchase had been concluded "on shipsboard out of cannon-shot of land," that is "on the open ocean or outside the jurisdiction of the English courts" - it would have become void at the latest when Yonga set foot on English soil. ${ }^{58}$ The purchase contract was thus invalid "as long as I [Yonga] as the only rightful master of my body and my freedom have not consented to it." 59 Only a contract by which Yonga had voluntarily entered into slavery or servitude (for example to secure his livelihood) could have been valid, but Borries was unable to provide evidence of such an agreement. ${ }^{60}$ Even if one assumed the right of the stronger according to natural law, Yonga's party argued, the defendant would have to demonstrate the just cause of his right (for example a crime committed by Yonga or his war captivity); a purchase contract was insufficient for this purpose. ${ }^{61}$

Yonga and his lawyer thus challenged the right of ownership of Captain Gordon, who explicitly identified himself as the owner in the purchase contract, as well as the possibility of a sale in England. An expert opinion commissioned from an English attorney confirmed that the young man had become free by stepping onto English soil and that the existing contract of 1765 was therefore void; the Somerset Case of 1772 in which Judge Mansfield had negated the existence of slavery in England, so the British lawyer argued, had not created new law - it had merely increased awareness of a legal situation that was already in effect. ${ }^{62}$

In fact, jurisdiction in England before as well as after the Somerset Case was far more ambiguous than the expert opinion suggested. ${ }^{63}$ It does show, however, how well

ending 7th May 1804 [ . . . ] 2 vols. (London: Samuel Bagster, 1805), vol. 2, 633 (overview); still seminal: E. V. Goveia, The West Indian Slave Laws of the 18th Century (Barbados: Caribbean Universities Press, 1970), 19-35. See also Hilary Beckles, "Social and Political Control in the Slave Society," in General History of the Caribbean, vol. 3, The Slave Societies of the Caribbean, ed. Franklin Knight (London: UNESCO, 1997), 194-221, especially 198-202; Bradley J. Nicholson, "Legal Borrowing and the Origins of Slave Law in the British Colonies," American Journal of Legal History 38 (1994): 38-54.

58 Staatsarchiv Detmold, L 83 A Nr. 12 J 247, fol. 52v and fol. 61v: "in der offenen See oder außer der Jurisdiction Englischer Gerichts-Höfe” (second quote).

59 Staatsarchiv Detmold, L 83 A Nr. 12 J 247, fol. 16r: "so lange ich [Yonga] als einziger rechtmäßiger Herr über meinen Körper so wie über meine Freyheit - darinn nicht consentirt habe.”

60 Staatsarchiv Detmold, L 83 A Nr. 12 J 247, fol. 42r.

61 Staatsarchiv Detmold, L 83 A Nr. 12 J 247, fol. 17v-18r. Borries' lawyer did in fact engage in such speculation at a later point (ibid., fol. $83 \mathrm{v}-84 \mathrm{v}$ ).

62 Staatsarchiv Detmold, L 83 A Nr. 12 J 247, fol. 53r-54r, 55r-v, 56v-57r. He made reference to several previous legal cases as evidence.

63 Cf. e.g. Kathleen Chater, Untold Histories: Black People in England and Wales During the Period of the British Slave Trade c. 1660-1807 (Manchester: Manchester University Press, 2009), especially 
Yonga and his attorney were informed and networked. They also mentioned the "free soil principle" that had recently been made legally binding in France and liberated slaves upon their entry into the country. ${ }^{64}$ The law was passed in 1791 on the very same day to which the corresponding letter by Yonga's counsel was dated, ${ }^{65}$ proving that he was fully abreast of the contemporary debate.

But Yonga's status up to his arrival in the County of Lippe was only one half of the legal dispute. The other half revolved around the question how Yonga's status in the Old Empire was to be assessed. The English expert argued that if a former slave who had been manumitted in England was returned to his enslaved status by entry into a country in which slavery still existed - in this case, Germany ${ }^{66}$ - this would represent a violation of the lex domicilii respectively the lex loci contractus that was respected between nations in other cases. ${ }^{67}$ He thus applied the principle of legal certainty between countries not to the relationship between Europe and its colonies like Hugo, but instead to the relationship between Great Britain and the Old Empire. On a different occasion, however, Yonga and his attorney argued vehemently for Yonga's legal status to be determined according to German law. ${ }^{68}$ In the Holy Roman Empire as the place of jurisdiction, they said, human beings were not regarded as things ${ }^{69}$ - "the more so as he [Borries] himself through his subsequent facta and my treatment has also foregone such a strict relationship." 70

Borries did not accept this reasoning, instead applying from the outset a twopronged strategy by substantiating his claim to ownership with the institute of slavery and that of serfdom:

But he was and remained despite all this a slave and my bonded servant as well as property purchased with money. And I could use him for the lowliest services of common Christian menials

77-101; Sheila Dziobon, “Judge, Jurisprudence and Slavery in England 1729-1807," in Colonialism, Slavery, Reparations and Trade, ed. Fernne Brennan and John Packer (New York: Routledge, 2012), 167-191. For example, Lord Mansfield stated in 1779 that the Somerset Case had not been about a fundamental decision on the legal status but merely about an owner not being allowed to force his slave to go to a different country. His contemporaries did not share this interpretation of his own words, however. In 1785, Mansfield released a community from the obligation to support an impoverished slave as the woman had not previously been recruited as a laborer, thereby confirming her enslaved status in England (Dziobon, “Judge, Jurisprudence and Slavery,” 180-181).

64 Staatsarchiv Detmold, L 83 A Nr. 12 J 247, fol. 46v-47r.

65 Frédéric Régent, La France et ses esclaves: De la colonisation aux abolitions 1620-1848 (Paris: Grasset, 2007), 307.

66 Staatsarchiv Detmold, L 83 A Nr. 12 J 247, fol. 56v.

67 Staatsarchiv Detmold, L 83 A Nr. 12 J 247, fol. 57r.

68 Staatsarchiv Detmold, L 83 A Nr. 12 J 247, fol. 19r.

69 Staatsarchiv Detmold, L 83 A Nr. 12 J 247, fol. 17v, 18v-19r.

70 Staatsarchiv Detmold, L 83 A Nr. 12 J 247, fol. 19v-20r: "Zumahlen Er [Borries] auch selbst durch seine nachherige facta und meine Behandlung auf ein dergleichen strenges Verhältniß [ . . . ] Verzicht geleistet hat.” 
without owing him anything but food and clothing: [ . . . ] and I was always free to sell him, barter him, or give him away at my discretion, until recently. Which I did; without my right of ownership being diminished or annulled by the baptism - as he has let others persuade him $[\ldots]^{71}$

After all, Borries argued, German serfs were not freed by baptism either. ${ }^{72}$ Had Yonga been a serf, however, Borries would not have been able to sell or transfer him independently of a manor. Yonga's side likewise disclaimed the classification as serf outright as "an institute that does not match the present case."73 At any rate, this was only the alternative line of reasoning for Borries and his counsel in the event that the status of enslavement, which they argued for in all its rigor including denial of Yonga's status as a person and legal capacity, ${ }^{74}$ should not be accepted:

[in] all of Germany - therefore also and all the more reliably in this County - there exists hitherto no law that nullifies or forbids it [i.e. the previously mentioned bondage]: Until then, however, according to the previously cited and very distinguished scholars of natural and international law [Hobbes, Grotius, Pufendorf, Vattel], there exists no forced obligation to release a bonded servant or slave against one's will, $[\ldots] .^{75}$

71 Staatsarchiv Detmold, L 83 A Nr. 12 J 247, fol. 8v: "Er war und blieb aber bey alle dem Sclave und mein leibeigener Knecht auch bar erkauftes Eigenthum. und ich konnte zu den niedrigsten diensten gemeiner christlicher Knechten ihn gebrauchen ohne ihm etwas weiter den solcher Kost und Bedeckung zu geben schuldig zu seyn: [ . . ] und mir stets frey ihn nach guthfinden wieder zu verkauffen, zu vertauschen und zu verschenken, bißletzten. was auch von mir geschehen; Ohne daß mein Eigenthumsrecht durch die Tauffe - wie er sich in den Kopf setzen lassen, dadurch vermindert oder aufgehoben [ . . . ]."

72 Staatsarchiv Detmold, L 83 A Nr. 12 J 247, fol. 8v-9r.

73 Staatsarchiv Detmold, L 83 A Nr. 12 J 247, fol. 22r: "ein Institut was auf gegenwärtigen Vorfall gar nicht paßt."

74 Staatsarchiv Detmold, L 83 A Nr. 12 J 247, fol. 29r, fol. 80r-v, fol. 82r-v. Yonga could therefore acquire no property, much less earn a wage as a domestic (fol. 29r). With regard to the lack of legal capacity, Borries' side referred explicitly to Roman law (fol. 78r). It even argued that African slaves could be punished, tormented, and indeed killed at their owner's discretion (fol. 82v). This was forbidden even under Roman law, however, and thus points to possible colonial influences: While enslaved persons in the Carribbean could not be killed arbitrarily, the corresponding sanctions in the shape of fines were comparatively minor (Goveia, West Indian Slave Laws, 20, 24-25, 28-29).

75 Staatsarchiv Detmold, L 83 A Nr. 12 J 247, fol. 30v: "[in] gantz deutschland - deshalb auch und umso zuverlässiger in hiesiger Graffschaft - noch kein Gesetze vorhanden, daß solche [d.h. die zuvor genannte 'Leib-Knechtschaft'] aufhebt oder verbietet: biß dahin aber nach eben angezogenen so angesehenen Natur- und Völkerrechts-Lehrern [Hobbes, Grotius, Pufendorf, Vattel], es keine ZwangVerbindlichkeit giebt, den leibeigenen Knecht oder Sclaven wieder willen loos zu geben, [ . . ].” Here Borries' side was borrowing directly from the Berlin legal opinion (see footnote 26: "Rechtsgeschichte eines erkauften Mohren") in terms of phrasing as well as in terms of the cited natural law scholars (Grotius, Pufendorf, Hobbes). The expert opinion had rejected Roman law for the case at hand as "nicht ganz so paßend noch anwendbar" ("not quite so fitting nor applicable") (fol. 36r-v) and instead referred to natural law. The "scholars of natural and international law" were merely mentioned and not discussed any further in the course of the trial in Lippe, however. 
Here slavery and serfdom were thus equated or at least presented as interchangeable and justified on the basis of natural law in order to maintain the right of ownership over the imported slave. This was possible since serfdom still existed in the Principality of Lippe, like in many other territories of the Empire, despite various efforts at reform in the second half of the eighteenth century. ${ }^{76}$ A fundamental repudiation of personal unfreedom would therefore have had repercussions for the institution of serfdom as well.

A third line of argumentation was aimed at recompense for costs incurred by Borries: He argued that it had been he who had made Yonga a human being in the first place through education and baptism, and had invested into him and provided food and clothing for him like for an illegitimate child until the act of transfer. ${ }^{77}$ That this had not occurred in mutual acquiescence for some time was evidenced by Borries' reference to Yonga's "repeated abscondence," which he likewise listed among his expenses. ${ }^{78}$ Regarding such compensation for the buyer, Borries' attorney referred to the "so splendid Prussian Code of Law serving as model for all legislation." Although the abovementioned general land law had not yet entered into force and did not even apply to the Principality of Lippe, the lawyer referred to it as exemplary. According to its provisions,

"[ . . . ] such a slave freed in this manner must serve his master without pay until he has recompensed the latter for the costs expended in his purchase." Could this law invalid in these lands be applied, then the plaintiff would have yet to serve a very long time before he had earned off the costs incurred for him. ${ }^{79}$

A special role in regard to the trial fell to the court of the Principality of Lippe: After an initial attempt by Prince Leopold as the new master/employer to defuse the

76 Serfdom was abolished in the Principality of Lippe in 1808, in some districts only in 1811/12 (Arndt, Fürstentum Lippe, 269-297). Until the end of the eighteenth century, individual manumissions and redemptions from serfdom occurred in parallel to an increasingly controversial discussion about the institution as a whole. Articles published in the periodical Lippische Intelligenzblätter under authority of the government as well as various reform-oriented writings suggested that an abolition of serfdom would promote demographic development as well as agricultural productivity. The repeated broaching of the topic in the State Diets of 1752, 1792, and 1793 produced no results, however (Lars Behrisch, Die Berechnung der Glückseligkeit: Statistik und Politik in Deutschland und Frankreich im späten Ancien Régime (Ostfildern: Thorbecke, 2016), 97, 122; Arndt, Fürstentum Lippe, 266-277).

77 Staatsarchiv Detmold, L 83 A Nr. 12 J 247, fol. 8r-9r, 30r.

78 Staatsarchiv Detmold, L 83 A Nr. 12 J 247, fol. 9v: "mehrmaliges Entlauffen," see also fol. 8r, 79v, 125r. According to Yonga's testimony, Borries had hit him on the head (ibid., fol. $127 \mathrm{vab}$ [sic]).

79 Staatsarchiv Detmold, L 83 A Nr. 12 J 247, fol. 89v-90r: “[ . . . ] so fürtrefliches zum Muster aller Gesetzgebung dienendes preußisches Gesetzbuch [ . . ] 'ein solcher hierdurch freigemachter Sclave seinem Herrn ohne Lohn so lange dienen müsse, bis er denselben dadurch für die auf seinen Ankauf verwendete Kosten entschädiget habe.' Könnte dieses in hiesigen Landen ungültige Gesetz Anwendung finden; so würde Kläger noch lange dienen müßen, ehe er die auf ihn verwendete Kosten abverdient hätte.” 
conflict was apparently unsuccessful, ${ }^{80}$ the court was asked for a statement in 1791. With the Prince having fallen ill, his Hofmarschall [lord steward] replied on his behalf: ${ }^{81}$ "To the Moor Wilhelm Jonka at his request is herewith certified: That he as a lackey at this princely court receives a fixed wage like the other court servants and furthermore is treated and regarded as a free person." ${ }^{82}$ While this statement was of no import concerning Yonga's legal status during his time with Borries, it does show that the court of Lippe had not maintained Yonga's enslaved status following the transfer. Yonga's marriage, which took place in 1789 shortly after the transfer, is likewise indicative of a status change. ${ }^{83}$ On the other hand, the Hofmarschall's statement cleverly avoided siding with either of the trial parties as well as assuming any responsibility for Yonga's fate. The latter's situation had taken a dire turn after his request for a wage raise had been denied in $1791 .{ }^{84}$ In his petition, Yonga stated that he had received only six and two-thirds Reichsthaler per month in the two years he had been working for the Prince. With such pay, he could "even with the strictest frugality [... ] not sustain my family and myself, but am forced to suffer privation and become poor." 85 While there was a moral duty of care for all persons in a state of dependence, the responsibility for an unfree person clearly lay with the owner. The Lippe court, however, denied ownership of Yonga.

At Borries' request and because the Principality of Lippe lacked a state university of its own, the princely judges sent the trial files to the faculty of law at the University of Rinteln in Hesse-Schaumburg for assessment in 1792. This was a common procedure at the time not only in smaller territories like Lippe. ${ }^{86}$ Half a year later, the Hessian experts sent back their decision, which allowed the judges in Lippe to put a preliminary end to the protracted dispute between the two parties: Not only was Borries able to furnish the purchase contract, ${ }^{87}$ but Yonga himself had admitted to serving Borries as a slave for the first four years; his baptism did not fundamentally

80 Staatsarchiv Detmold, L 114 von Borries Nr. 4 [unfoliated]; Staatsarchiv Detmold, L 83 A Nr. 12 J 247, fol. 32r, 41r.

81 Staatsarchiv Detmold, L 83 A Nr. 12 J 247, fol. 78v-79v.

82 Staatsarchiv Detmold, L 83 A Nr. 12 J 247, fol. 63r: "Dem Mohr Wilhelm Jonka, wird auf sein Verlangen hierdurch bezeuget: daß er als Laquai bei hiesigem fürstlichen Hofe, so wie die anderen Hofbedienten einen fixirten Gehalt bekomme und übrigens dabei, als ein freier Mensch behandelt und betrachtet werde."

83 Bechtel, “Der 'Kammermohr’ Franz Wilhelm Yonga,” 11 and 21.

84 Staatsarchiv Detmold, L 92 P Nr. 120 [unfoliated].

85 Staatsarchiv Detmold, L 92 P Nr. 120 [unfoliated]: “auch bei der strengsten Sparsamkeit [ . . . ] meine Familie und mich nicht ernähren, sondern muß Noth leiden und arm dabei werden.” In 1794, he had six children and earned eight Reichstaler per month (Staatsarchiv Detmold, L 77 B Nr. 129, fol. 49v).

86 Arndt, Fürstentum Lippe, 103.

87 This and the following three quotations: Staatsarchiv Detmold, L 83 A Nr. 12 J 247 , fol. 104v-106r: "ohnehin gemilderte wohl erworbenen Rechte der Knechtschaft"; "Servitut der Negern"; "nach römischen Rechten.” 
change this status, and there was no law in Germany that abrogated the "already extenuated vested rights of bondage." The "servitude of Negroes" was to be assessed "according to Roman law" in Germany, as the judges asserted with reference to Höpfner, and the opinion of the British expert was not verifiable. ${ }^{88}$ Hence

Princely Lippian President and Councilors appointed to government, following the presented counsel of external legal scholars, herewith adjudge: That the defendant [Borries] is to be acquitted of the filed suit, unless the plaintiff [Yonga] is able to demonstrate better than has been done that he had received his freedom according to British laws or customs at the time of the purchase having occurred in 1765 or through his residence in England. ${ }^{89}$

A praesumptio pro libertate or a disenthrallment by setting foot on European soil (free soil principle) were thus rejected for England as well as for the Old Empire. The councilors not only confirmed that Borries had lawfully purchased Yonga as a slave; they also confirmed the persistence of this legal status in Germany. They substantiated their verdict neither with the validity of colonial nor British laws in the Old Empire but instead with Roman law, which they declared applicable to the "servitude of Negroes" in Germany. Serfdom, on the other hand, served merely to confirm the persistence of unfree living conditions in generic terms. The legal experts and judges also appeared unimpressed by the Prussian general land law as a model for other German territories: They mentioned neither manumission nor compensation for the purchaser. Even the scholars of natural and international law cited by Borries' side in justification of the slave status - Thomas Hobbes (1588-1679), Hugo Grotius (1583-1645), Samuel Pufendorf (1632-1694), and Emer de Vattel (1714-1767) - played no role for the verdict. Rather, in combination with Höpfner's publications, this case shows how long Roman law influenced judicial teaching and legal practice - and hence that slavery was regarded as a lawful form of unfreedom in early modern Germany until the late eighteenth century.

\section{Conclusion}

Court disputes as in the case of Yonga were the exception in early modern Germany. African servants had to be of sufficient age and needed courage, knowledge, resources, an opportunity, and the prospect of actually improving their situation in order

88 Borries' side had previously complained that the document was not a published court verdict but merely the legal opinion of a lawyer (Staatsarchiv Detmold, L 83 A Nr. 12 J 247, fol. 85r-87r).

89 Staatsarchiv Detmold, L 83 A Nr. 12 J 247, fol. 107r-v: "Fürstlich Lippische zur Regierung verordnete Praesident und Räthe, nach vorgehaltenen Rath auswärtiger Rechtsgelehrten hiermit für Recht: Daß Beklagter von der angestellten Klage zu entbinden, es könnte denn Kläger besser als geschehen, darthun, daß er nach englischen Gesetzen oder Gewohnheiten zur Zeit des im Jahr 1765 geschehenen Ankaufs oder durch seinen Aufenthalt in England die Freiheit erhalten habe.” 
to litigate. In light of the generally young age at which they were enslaved, their vulnerability and dependency owed to a lack of family networks and the scarcity of employment perspectives outside of the courts, such circumstances were rare. ${ }^{90}$ How strong (or perhaps how desparate) Yonga must have been is evidenced by the fact that he furnished a second expert opinion immediately after the pronouncement of the verdict. ${ }^{91}$ This initiative ultimately led to a compromise settlement with Borries' widow after Borries himself had died in 1795: Yonga agreed to refrain from bringing further lawsuits in return for a payment of one hundred Reichstaler.

We know, however, that a lack of alternatives could lead African servants to resign themselves to their fate: August Wilhelm Peter, for example, returned to the Brunswick court following a brief absence "after not having found the fortune he had hoped for in Berlin and Magdeburg [ . . . ." 92 How strong the dependency on a patron was is also apparent in Yonga's own strategy in a different situation, namely when he was faced with potential removal from the court in 1794 as the result of an intrigue: "He begs imploringly not to be expelled from the country, and has nothing to offer in his excuse other than that he is gifted to His Highness the Prince, belongs to the same personally and cannot leave You." 93 Here Yonga attempted to use the ownership relation, which the court of Lippe had not even laid claim to, for his own protection and succor.

The few available documents on court disputes discovered so far should not lead us to believe that slavery itself was exceptional in the Old Empire, however: The available legal literature clearly speaks against such a conceptual exceptionalism that regards every one of these biographies as a special or isolated case. It is clear that the judges in the Yonga case did not make an ad hoc decision: They were able to refer not only to contemporary legal literature but to an entire legal tradition in Germany. This tradition went back to the sixteenth century and to Samuel Stryk

90 Rebekka v. Mallinckrodt, "Verschleppte Kinder im Heiligen Römischen Reich Deutscher Nation und die Grenzen transkultureller Mehrfachzugehörigkeit,” in Transkulturelle Mehrfachzugehörigkeiten: Räume, Materialitäten, Erinnerungen, ed. Dagmar Freist, Sabine Kyora, and Melanie Unseld (Bielefeld: transcript, 2019), 15-37; Vera Lind, "Privileged Dependency on the Edge of the Atlantic World: Africans and Germans in the Eighteenth Century," in Interpreting Colonialism, ed. Byron R. Wells and Philip Stewart (Oxford: Voltaire Foundation, 2004), 369-391.

91 This and the following: Staatsarchiv Detmold, L 114 v. Borries Nr. 4 [unfoliated], letter from Prince Leopold on November 13, 1795; Staatsarchiv Detmold, L 83 A Nr. 12 J 247, fol. 117r-120r, 122v-123r, 141r-v; Staatsarchiv Detmold, L 92 A Nr. 1190, fol. 5r.

92 Martin, Schwarze Teufel, edle Mohren, 157: "nachdem er seine Fortun in Berlin und Magdeburg gehoffter maßen nicht gefunden [. . . ].”

93 Staatsarchiv Detmold, L 77 B Nr. 129, fol. 40r: "Er bittet flehentlich: nicht außer Land gesezt zu werden und weis zu seiner Entschuldigung nichts an zu führen, als daß er Sr Durchlt. dem Fürsten geschenkt sey, Höchstdenselben eigen gehöre und Sie nicht verlassen könne.” As a result of this dependency, respectively of the "devotedness" mentioned in the sources, he was allowed to return to his work as footman (ibid., fol. 52r-v). Besides, Yonga had achieved such a position of trust that he was to remain at the court so as not to endanger the health of the Prince (ibid., fol. 13v-14r). 
(1640-1710), whose work Specimen usus moderni Pandectarum (1690) lent its name to the early modern interpretation of Roman law and was likewise mentioned in the verdict of the Yonga case. This legal tradition suggests the need for a long-term and systemic consideration of enslavement practices in the Old Empire. Furthermore, it shows that the Holy Roman Empire as a Central European land power was not just involved in the transatlantic slave trade but also strongly influenced by the experience of reciprocal enslavement during the Ottoman Wars, which still resonated in late-eighteenth-century legal texts.

The analysis of these legal texts can not only reveal which instruments were available for court proceedings. It can also illustrate long-term changes in the history of mentalities: Did Roman law represent a legal source used continuously since its reception in the sixteenth century for the justification of slavery in Europe, or is it only at the time when the number of abducted and enslaved persons in Europe rose considerably during the eighteenth century that we encounter increasing references to this source? Since the question of slavery stood at the very beginning of engagement with Roman law, which in turn was obligatory for all early modern law students, do we find arguments for (and against) slavery only in expert opinions or also in the countless publications and correspondences of the many students of law who never entered the administrative and judiciary systems ${ }^{94}$ but introduced jurisprudential perspectives into various other areas of life? In any case, this contribution has been able to show that Roman slavery was not merely a touchstone against which other contemporary forms of unfreedom respectively colonial slavery could be measured, as John W. Cairns argues. ${ }^{95}$ In fact, even in early modern Germany, it was a template and an applied model as well.

\title{
References
}

\section{Archival Sources}

\author{
Staatsarchiv Detmold \\ L 77 B Nr. 129. \\ L 83 A Nr. 12 J 247. \\ L 92 A Nr. 1190. \\ L 92 P Nr. 120. \\ L 98 Nr. 62. \\ L 114 v. Borries Nr. 4.
}

94 Ina Ebert, “Jurist,” in Enzyklopädie der Neuzeit, ed. Friedrich Jaeger, vol. 6 (Stuttgart: Metzler, 2007), col. 190-195, here col. 194.

95 John W. Cairns, "The Definition of Slavery in Eighteenth-Century Thinking: Not the True Roman Slavery," in The Legal Understanding of Slavery. From the Historical to the Contemporary, ed. Jean Allain (Oxford: Oxford University Press, 2012), 61-85, here 65, 73, 84. 


\section{Printed Sources}

Acta Borussica: Denkmäler der Preußischen Staatsverwaltung im 18. Jahrhundert, edited by Preußische Akademie der Wissenschaften. Vol. 13. Berlin: Parey, 1932.

Allgemeines Landrecht für die Preußischen Staaten von 1794, edited by Hans Hattenhauer and Günther Bernert. $2^{\text {nd }}$ ed. Neuwied: Luchterhand, 1994.

Corpus Iuris Civilis: Die Institutionen. Text und Übersetzung, edited by Rolf Knütel et al. Heidelberg: Müller, 2013.

Höpfner, Ludwig Julius Friedrich. Theoretisch-practischer Commentar über die Heineccischen Institutionen. $1^{\text {st }}-6^{\text {th }}$ ed. Frankfurt: Varrentrapp \& Wenner, 1783, 1787, 1790, 1793, 1795, 1798. Hugo, Gustav. Civilistisches Magazin. Vol. 1. Berlin: Mylius, 1791.

Meusel, Johann G. Lexikon der vom Jahr 1750 bis 1800 verstorbenen teutschen Schriftsteller. Vol. 8. Leipzig: Fleischer, 1806.

"Rechtsgeschichte eines erkauften Mohren.” Beyträge zu der juristischen Litteratur in den preußischen Staaten 6. Sammlung, 4. Abschnitt (1780): 296-319.

Runde, Justus Friedrich. Grundsätze des allgemeinen deutschen Privatrechts. Göttingen: Johann Christian Dieterich, 1791.

Savigny, Friedrich Carl v. "Der zehnte Mai 1788: Beytrag zur Geschichte der Rechtswissenschaft." Zeitschrift für geschichtliche Rechtswissenschaft 9 (1838): 421-432.

Schaumburg, Gottfried. Einleitung zum Sächsischen Rechte. $2^{\text {nd }}$ ed. Vol. 1. Dresden: Gerlach, 1768.

Schlichtegroll, Friedrich. Nekrolog auf das Jahr [. . .]. Vol. 8,2. Gotha: Perthes, 1797, published 1802.

Strieder, Friedrich Wilhelm. Grundlage zu einer Hessischen Gelehrten- und Schriftsteller-Geschichte. Vol. 6. Cassel: Cramer, 1786.

The Laws of the Island of Antigua: Consisting of the Acts of the Leeward Islands, Commencing 8th November 1690, ending 21st April 1798; and the Acts of Antigua, Commencing 10th April 1668, ending 7th May 1804 [. . .]. 2 vols. London: Samuel Bagster, 1805.

Weidlich, Christoph. Biographische Nachrichten von den jetztlebenden Rechts-Gelehrten in Teutschland. Vol. 1. Halle: Hemmerde, 1781.

\section{Literature}

Arndt, Johannes. Das Fürstentum Lippe im Zeitalter der Französischen Revolution 1770-1820. Münster: Waxmann, 1992.

Bärwald, Annika, Josef Köstlbauer, and Rebekka v. Mallinckrodt. "People of African Descent in Early Modern Europe." In Oxford Bibliographies Online: Atlantic History, edited by Trevor Burnard. Last modified January 15, 2020. https://doi.org/10.1093/obo/9780199730414-0326.

Becker, Andreas. "Preußens schwarze Untertanen: Afrikanerinnen und Afrikaner zwischen Kleve und Königsberg vom 17. Jahrhundert bis ins frühe 19. Jahrhundert." Forschungen zur Brandenburgischen und Preußischen Geschichte 22 (2012): 1-32.

Bechtel, Wolfgang. “Der 'Kammermohr' Franz Wilhelm Yonga." Lippische Mitteilungen aus Geschichte und Landeskunde 84 (2015): 11-35.

Beckles, Hilary. "Social and Political Control in the Slave Society." In General History of the Caribbean. Vol. 3, The Slave Societies of the Caribbean, edited by Franklin Knight, 194-221. London: UNESCO, 1997.

Behrisch, Lars. Die Berechnung der Glückseligkeit: Statistik und Politik in Deutschland und Frankreich im späten Ancien Régime. Ostfildern: Thorbecke, 2016. 
Blickle, Peter. Von der Leibeigenschaft zu den Menschenrechten: Eine Geschichte der Freiheit in Deutschland. Munich: C. H. Beck, 2006.

Cairns, John W. "The Definition of Slavery in Eighteenth-Century Thinking: Not the True Roman Slavery." In The Legal Understanding of Slavery: From the Historical to the Contemporary, edited by Jean Allain, 61-85. Oxford: Oxford University Press, 2012.

Chater, Kathleen. Untold Histories: Black People in England and Wales During the Period of the British Slave Trade c. 1660-1807. Manchester: Manchester University Press, 2009.

Deissler, Johannes. Antike Sklaverei und deutsche Aufklärung im Spiegel von Johann Friedrich Reitemeiers "Geschichte und Zustand der Sklaverey und Leibeigenschaft in Griechenland" 1789. Stuttgart: Steiner, 2000.

Diedrich, Maria I. "From American Slaves to Hessian Subjects: Silenced Black Narratives of the American Revolution." In Germany and the Black Diaspora: Points of Contact 1250-1914, edited by Mischa Honeck, Martin Klimke, and Anne Kuhlmann, 92-111. New York: Berghahn, 2013.

Dziobon, Sheila. “Judge, Jurisprudence and Slavery in England 1729-1807." In Colonialism, Slavery, Reparations and Trade, edited by Fernne Brennan and John Packer, 167-191. New York: Routledge, 2012.

Ebert, Ina. “Jurist.” In Enzyklopädie der Neuzeit, edited by Friedrich Jaeger, vol. 6, col. 190-195. Stuttgart: Metzler, 2007.

Firla, Monika. "Afrikanerinnen und ihre Nachkommen im deutschsprachigen Raum." In AfrikanerInnen in Deutschland und schwarze Deutsche: Geschichte und Gegenwart, edited by Marianne Bechhaus-Gerst and Reinhard Klein-Arendt, 9-24. Münster: Lit, 2004.

Goveia, E. V. The West Indian Slave Laws of the 18th Century. Barbados: Caribbean Universities Press, 1970.

Haarnack, Carl. "Duitsers in Suriname.” Buku: Bibliotheca Surinamica. Accessed June 26, 2020. https://bukubooks.wordpress.com/duitsers.

Häberlein, Mark. “'Mohren,' ständische Gesellschaft und atlantische Welt.” In Atlantic Understandings: Essays on European and American History in Honor of Hermann Wellenreuther, edited by Claudia Schnurmann and Hartmut Lehmann, 77-102. Hamburg: Lit, 2006.

Hanß, Stefan and Juliane Schiel. "Semantiken, Praktiken und transkulturelle Perspektiven." In Mediterranean Slavery Revisited 500-1800, edited by Stefan Hanß and Juliane Schiel, 25-43. Zurich: Chronos, 2014.

Heger, Martin. "Recht im ‘Alten Reich’: Der Usus modernus.” Zeitschrift für das Juristische Studium 1 (2010): 29-39.

Kischkel, Thomas Cornelius. "Das Naturrecht in der Rechtspraxis: Dargestellt am Beispiel der Spruchtätigkeit der Gießener Juristenfakultät.” Zeitschrift für Neuere Rechtsgeschichte 22 (2000): 124-147.

Klippel, Diethelm. "Politische und juristische Funktionen des Naturrechts in Deutschland im 18. und 19. Jahrhundert: Zur Einführung." Zeitschrift für Neuere Rechtsgeschichte 22 (2000): 3-10.

Kriedte, Peter. "Vom Großhändler zum Detaillisten: Der Handel mit Kolonialwaren im 17. und 18. Jahrhundert." Jahrbuch für Wirtschaftsgeschichte 1 (1994): 11-36.

Kuhlmann-Smirnov, Anne. Schwarze Europäer im Alten Reich: Handel, Migration, Hof. Göttingen: V \& R Unipress, 2013.

Lentz, Sarah. “'[S]o kann ich jetzt als ein Augenzeuge auftreten.' Deutsche Profiteure des atlantischen Sklavereisystems und der deutschsprachige Sklavereidiskurs der Spätaufklärung." In Das Meer: Maritime Welten in der Frühen Neuzeit, edited by Peter Burschel and Sünne Juterczenka. Cologne: Böhlau, forthcoming.

Lentz, Sarah. '“Oh Wonderful Sugar Beet! You Are the Death of the Bloody Sugar Cane.' The German Debate on the Morality of the Consumption of Sugar Produced by Slave Labour Around 1800." 
In Moralizing Commerce in a Globalizing World, edited by Felix Brahm and Eve Rosenhaft. Oxford: Oxford University Press, forthcoming.

Lind, Vera. "Privileged Dependency on the Edge of the Atlantic World: Africans and Germans in the Eighteenth Century." In Interpreting Colonialism, edited by Byron R. Wells and Philip Stewart, 369-391. Oxford: Voltaire Foundation, 2004.

Mallinckrodt, Rebekka v. "Sklaverei und Recht." In Das Meer: Maritime Welten in der Frühen Neuzeit, edited by Peter Burschel and Sünne Juterczenka. Cologne: Böhlau, forthcoming.

Mallinckrodt, Rebekka v. "There Are No Slaves in Prussia?" In Slavery Hinterland: Transatlantic Slavery and Continental Europe, 1680-1850, edited by Felix Brahm and Eve Rosenhaft, 109-131. Woodbridge: Boydell \& Brewer, 2016.

Mallinckrodt, Rebekka v. "Verhandelte (Un-)Freiheit: Sklaverei, Leibeigenschaft und innereuropäischer Wissenstransfer am Ausgang des 18. Jahrhunderts." Geschichte \& Gesellschaft 43, no. 3 (2017): 347-380.

Mallinckrodt, Rebekka v. "Verschleppte Kinder im Heiligen Römischen Reich Deutscher Nation und die Grenzen transkultureller Mehrfachzugehörigkeit.” In Transkulturelle

Mehrfachzugehörigkeiten: Räume, Materialitäten, Erinnerungen, edited by Dagmar Freist, Sabine Kyora, and Melanie Unseld, 15-37. Bielefeld: transcript, 2019.

Martin, Peter. Schwarze Teufel, edle Mohren: Afrikaner in Geschichte und Bewußtsein der Deutschen. Hamburg: Hamburger Edition, 2001.

Nicholson, Bradley J. "Legal Borrowing and the Origins of Slave Law in the British Colonies." American Journal of Legal History 38 (1994): 38-54.

Patterson, Orlando. Slavery and Social Death: A Comparative Study. Cambridge, MA: Harvard University Press, 1982.

Pielemeier, Ines and Jan Schröder. "Naturrecht als Lehrfach an den deutschen Universitäten des 18. und 19. Jahrhunderts." In Naturrecht - Spätaufklärung - Revolution, edited by Otto Dann and Diethelm Klippel, 255-269. Hamburg: Meiner, 1995.

Plohmann, Michael. Ludwig Julius Friedrich Höpfner (1743-1797): Naturrecht und positives Privatrecht am Ende des 18. Jahrhunderts. Berlin: Duncker \& Humblot, 1992.

Régent, Frédéric. La France et ses esclaves: De la colonisation aux abolitions 1620-1848. Paris: Grasset, 2007.

Scholz, Luca. "Leibeigenschaft rechtfertigen: Kontroversen um Ursprung und Legitimität der Leibeigenschaft im Wildfangstreit.” Zeitschrift für Historische Forschung 45, no. 1 (2018): 41-81.

Schröder, Jan. “'Naturrecht bricht positives Recht' in der Rechtstheorie des 18. Jahrhunderts?" In Staat, Kirche, Wissenschaft in einer pluralistischen Gesellschaft: Festschrift zum 65. Geburtstag von Paul Mikat, edited by Dieter Schwab et al., 419-433. Berlin: Duncker \& Humblot, 1989.

Schulze, Winfried. “Die Entwicklung eines ‘teutschen Bauernrechts' in der Frühen Neuzeit.” Zeitschrift für Neuere Rechtsgeschichte 12 (1990): 127-163.

Söllner, Alfred. "Ludwig Julius Friedrich Höpfner - ein Mitglied der Gießener Juristenfakultät im 18. Jahrhundert." In Festschrift für Walter Mallmann, edited by Otto Triffterer and Friedrich von Zezschwitz, 281-292. Baden-Baden: Nomos, 1978.

Stagl, Jakob F. "Die Personwerdung des Menschen: Anfänge im Römischen Recht.” In Personen: Zum Miteinander einmaliger Freiheitswesen, edited by Hans Thomas and Johannes Hattler, 89-109. Berlin: De Gruyter, 2012.

Steffen, Anka and Klaus Weber. "Spinning and Weaving for the Slave Trade: Proto-Industry in Eighteenth-Century Silesia." In Slavery Hinterland: Transatlantic Slavery and Continental Europe, 1680-1850, edited by Felix Brahm and Eve Rosenhaft, 87-107. Woodbridge: Boydell \& Brewer, 2016. 
Ulmschneider, Christoph. Eigentum und Naturrecht im Deutschland des beginnenden

19. Jahrhunderts. Berlin: Duncker \& Humblot, 2003.

Wardemann, Patricia. Johann Gottlieb Heineccius (1681-1741): Leben und Werk. Frankfurt: Peter Lang, 2007.

Weber, Klaus. "Deutschland, der atlantische Sklavenhandel und die Plantagenwirtschaft der Neuen Welt." Journal of Modern European History 7 (2009): 37-67.

Weber, Klaus. "Mitteleuropa und der transatlantische Sklavenhandel: Eine lange Geschichte." Werkstatt Geschichte 66/67 (2015): 7-30.

Wiese, Marion. Leibeigene Bauern und Römisches Recht im 17. Jahrhundert: Ein Gutachten des David Mevius. Berlin: Duncker \& Humblot, 2006.

Zeuske, Michael and Jörg Ludwig. "Amerikanische Kolonialwaren in Preußen und Sachsen: Prolegomena." Jahrbuch für Geschichte von Staat, Wirtschaft und Gesellschaft Lateinamerikas 32 (1995): 257-302.

Zeuske, Michael. Handbuch Geschichte der Sklaverei: Eine Globalgeschichte von den Anfängen bis zur Gegenwart. Berlin: De Gruyter, 2013. 


\section{From Slave Purchases to Child Redemption: A Comparison of Aristocratic and Middle-Class Recruiting Practices for "Exotic" Staff in Habsburg Austria}

Dark-skinned domestics are well-known to us as a characteristic element of aristocratic representation in early modern times. They served at the courts of kings and princes, archbishops and abbesses, leaving traces in art and literature as well as in certain customs and traditions. Their presence outlasted the Baroque period, however. We encounter them again in the households of the upper class during the nineteenth century, sometimes even later - despite the abolition of slavery and the slave trade in Europe, despite the societal changes brought about by the industrial revolution, and despite the fact that the structure of the public was changing fundamentally. The desire among the elites to exoticize their public as well as private lives by instrumentalizing persons from overseas had become a cross-epochal constant. At the same time, however, the political and legal framework conditions for recruiting ${ }^{1}$ and employing Black domestic servants had changed fundamentally, so that we must ask about the underlying structures allowing the practice to be maintained. The following text, which is embedded in a larger research project on slave trading and slavery in Austrian history, therefore explores - using a comparative approach - the changes in the function of "exotic servants" and the practices for procuring them during and after the era of the transatlantic respectively trans-Mediterranean slave trade, i.e. between the sixteenth and eighteenth centuries on the one hand and during the nineteenth century on the other.

\section{"Exotic" Domestics and Feudal Representation}

The Prince [. . .] traveled in a magnificent gala carriage drawn by six black horses, in a goldembroidered coatdress and hat with white imperial feathers. The stablemaster rode ahead of the carriage, accompanied by grooms leading six horses with richly embroidered blankets. They were followed by the princely court forager Bauer on a horse, accompanied by two porters, six

1 Technical collective terms like "procuring" or "recruiting" are intentionally used to subsume the various different practices that will be mentioned in this text. This phrasing is not intended to trivialize the fact that many of these practices were violent and inhumane.

Translation: Stephan Stockinger

Ә Open Access. ( 2021 Walter Sauer, published by De Gruyter. (c) BY-NC-ND This work is licensed under the Creative Commons Attribution-NonCommercial-NoDerivatives 4.0 International License.

https://doi.org/10.1515/9783110748833-007 